\title{
A preliminary analysis of the reduction of chemotherapy waste in the treatment of cancer with centralization of drug preparation
}

\author{
Adriano Hyeda ${ }^{1 *}$, Elide Sbardellotto Mariano da Costa ${ }^{2}$ \\ ${ }^{1}$ Specialist in clinical oncology at the Universidade Federal do Paraná (UFPR). Occupational physician from the Pontifícia Universidade Católica do Paraná (PUC-PR). Executive MBA in Healt at Instituto \\ Superior de Administração e Economia/Fundação Getúlio Vargas (ISAE/FGV), Curitiba, PR, Brazil \\ ${ }^{2}$ Medical auditor. Specialist in Cardiology by PUC-PR. Executive MBA in Health by ISAE/FGV, Curitiba, PR, Brazil
}

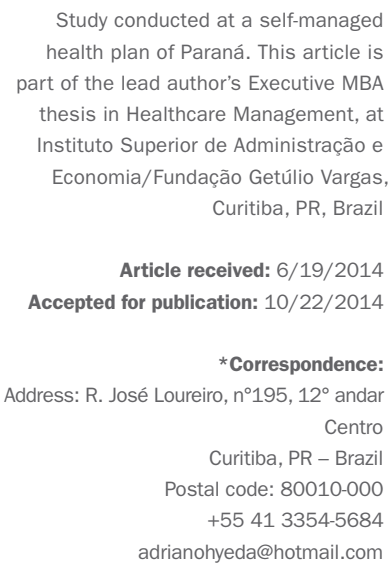

Study conducted at a self-managed health plan of Paraná. This article is part of the lead author's Executive MBA thesis in Healthcare Management, at Instituto Superior de Administração e Economia/Fundação Getúlio Vargas, Curitiba, PR, Brazil

Article received: 6/19/2014 Accepted for publication: 10/22/2014

*Correspondence: Address: R. José Loureiro, n¹95, $12^{\circ}$ andar Centro Curitiba, PR - Brazi Postal code: $80010-000$ +55 $413354-5684$ adrianohyeda@hotmail.com

http://dx.doi.org/10.1590/1806-9282.61.04.368 Conflict of interest: none

\section{SUMmARY}

Introduction: chemotherapy is essential to treat most types of cancer. Often, there is chemotherapy waste in the preparation of drugs prescribed to the patient. Leftover doses result in toxic waste production.

Objective: the aim of the study was to analyze chemotherapy waste reduction at a centralized drug preparation unit.

Methods: the study was cross-sectional, observational and descriptive, conducted between 2010 and 2012. The data were obtained from chemotherapy prescriptions made by oncologists linked to a health insurance plan in Curitiba, capital of the state of Paraná, in southern Brazil. Dose and the cost of chemotherapy waste were calculated in each application, considering the dose prescribed by the doctor and the drug dosages available for sale. The variables were then calculated considering a hypothetical centralized drug preparation unit.

Results: there were 176 patients with a cancer diagnosis, 106 of which underwent treatment with intravenous chemotherapy. There were 1,284 applications for intravenous anticancer medications. There was a total of $63,824 \mathrm{mg}$ in chemotherapy waste, the cost of which was BRL 448,397.00. The average cost of chemotherapy waste per patient was BRL 4,607.00. In the centralized model, there was $971.80 \mathrm{mg}$ of chemotherapy waste, costing BRL 13,991.64. The average cost of chemotherapy waste per patient was BRL 132.00.

Conclusion: the use of centralized drug preparation units may be a strategy to reduce chemotherapy waste.

Keywords: chemotherapy, health services administration, good manipulation practices, medical waste, neoplasia.

\section{INTRODUCTION}

The change in the demographic profile of Brazil, with increasing population longevity associated with changes in lifestyle, is responsible for the change in the population morbidity and mortality profile. Exposure to the risk factors of contemporary society, such as poor nutrition, physical inactivity, increased excess weight, smoking, excessive use of alcohol and other drugs, provided an epidemiological transition with a predominance of chronic noncommunicable diseases (NCDs), including cancer in its various manifestations. ${ }^{1,2}$ The Ministry of Health (MC) and the National Cancer Institute (INCA) estimate about 580,000 new cases in $2014 .^{3}$

According to a study from the Harvard Medical School of Public Health/World Economic Forum, it was conclud- ed that the 13.3 million new cancer cases in 2010 led to a cost of USD 290 billion. The cost of medication represented USD 154 billion (53\% of total). There is an estimated increase of $36.7 \%$ in the total cost of treating cancer by 2030 , that is, USD 458 billion..$^{4-6}$

Chemotherapy is one of the main treatments for cancer. It refers to the use of chemical agents in order to kill cancer cells or inhibit their growth and proliferation. ${ }^{7}$

In Brazil, the preparation and the application of chemotherapy is performed in oncology services from the public and private health systems. Typically, each clinic has its own chemotherapy manipulation center. The Brazilian Health Surveillance Agency (Anvisa) has the authority to regulate and supervise the operation of these services through technical operating standards..$^{8-11}$ 
In the process of preparing chemotherapy medication from vials and ampoules with the presentation dose commercialized, part of the drug ends up being discarded to attain the dose prescribed by the doctor, resulting in toxic waste. The National Environment Council (Conama) classifies chemotherapy waste as group B, that is, waste that represents potential risk to public health and the environment due to its chemical characteristics. ${ }^{12-14}$ In addition to the environmental impact of the waste produced, one must consider the analysis of the cost related to unused medication.

The perspective of a significant increase in the number of cancer cases, coupled with the high cost of treatment, partly related to the development and incorporation of new drugs, is a critical and concerning factor for the public and private health systems in the country. As such, all necessary measures to improve the use of resources in cancer treatment, as well as prevention and health promotion, must be studied and used to ensure the economic sustainability of the country's health system.

In this context, various strategies have been suggested to assure efficient cancer treatment. One of them is the promotion of medicine based on evidence and the adoption of endpoints validated both in clinical studies and drug approval processes. Research on relevant biomarkers to better identify responsive patients may contribute to the proper selection of treatment. The appropriate allocation of health system resources in disease prevention and early detection of cancer can reduce costs with advanced disease. ${ }^{15,16}$

Furthermore, the production and use of biosimilar medication is under discussion. These are drugs developed from the loss of patent protection of the reference medication, which must have the same active ingredient, concentration, pharmaceutical form and route of administration. The advantage is in the 25 to $30 \%$ reduction in price of medication. ${ }^{17}$ On the other hand, there are uncertainties regarding the real efficacy and quality assurance of the product.

Finally, management of chemotherapy waste is a shortterm strategy which allows a reduction of costs and guarantees the quality of treatment. There is evidence of a reduction of $45 \%$ in expenses with unused chemotherapy doses in two years of monitoring. 15,16

There are no studies evaluating the amount of chemotherapy discarded in the cancer treatment model adopted in Brazil. Knowing this indicator, as well as adopting management measures on chemotherapy waste, may be an appropriate short-term strategy to reduce costs and ensure the sustainability of cancer care in the country.
The objective of this study was to conduct an analysis of chemotherapy waste from medical prescriptions from a group of oncology service providers during two years of monitoring. Furthermore, the strategies for reducing the production of chemotherapy waste were discussed.

\section{Methods}

This was an observational cross-sectional study from July 2010 to August 2012 in a health plan of the self-management category in the state of Paraná, Brazil, with 16,660 users. ${ }^{9}{ }^{18}$ Seven oncology clinics were monitored, all accredited by health plan and located in the same city. Technical rule approved by Anvisa in 2004. ${ }^{8}$

All medical chemotherapy prescriptions were sent to the medical auditors of the health plan in order to examine treatment conformity. ${ }^{19,20}$ All information required for the study was obtained from the analysis of prescription for each patient. The data used were: age and sex of the patient, body surface area, type of cancer, chemotherapy regimen used, medication and the prescribed dose per day of treatment. Any additional information that could identify the patient was excluded from the study. Oral or subcutaneous medication prescriptions and treatments carried out outside the clinics were excluded (e.g. hospital admission).

Chemotherapy regimen is the treatment plan for the cancer, determined by the oncologist. It is constituted of a series of repeated treatment periods denominated cycles. In each cycle, the patient may receive chemotherapy for one or more days, successively or otherwise. Considering that chemotherapy also acts on healthy cells, there are periods of rest during the cycle in which no treatment is received. This rest period allows the patient's body to recover and produce new healthy cells. ${ }^{7}$ The chemotherapy regimens performed during the study period were determined by each patient's oncologist, without interference from the medical auditors of the health plan.

The calculation of the chemotherapy dose depends on the treatment protocol selected by the oncologist, as well as weight or the body surface area of the patient. Other variables can also interfere with the determination of the dose: age, comorbidities, patient performance, side effects of medication, etc. ${ }^{7}$ Therefore, the chemotherapy dose is not fixed and may vary between patients using the same protocol. The application may also vary from one patient to another. In the study, the chemotherapy dose was determined by the oncologist and recorded in the patient's prescription. The health plan's medical auditors did not interfere in determination of the dose or prescription by the oncologist. 
The discarded chemotherapy dose was calculated based on the dose prescribed by the physician and the commercialized dose of each drug. Toxic waste is the sum of discarded doses of each chemotherapy session for all applications conducted in the study period.

The cost of chemotherapy was calculated according to the commercial presentation used most by the oncology clinics in the study. Prices were consulted in Brasindice Pharmacentical Guide, number 796, year 49 - January 10, 2014. ${ }^{21}$ To determine the value of chemotherapy medication, the authors used the factory price at $12 \%$ (FP12\%), considering that the clinics are in the state of Paraná. The authors, then, calculated the cost per milligram of each medication in national currency (BRL). Finally, the sum of the total chemotherapy dose discarded was multiplied by the cost of each milligram of medication. Adding the cost of the discarded dose of each medication, the chemotherapy waste cost was obtained.

In order to evaluate the impact of the centralized model in reducing chemotherapy waste, a hypothetical model was developed, considering that all chemotherapy applications were carried out in only one clinic in the same day. In this case, the minimum chemotherapy dose discarded was obtained considering the sum of the total prescribed dose in a single day and the commercial presentation of each medication.

The study data were obtained from the evaluation of chemotherapy prescriptions by the medical auditor of the health provider, and recorded on an Excel $^{\circledR}$ spreadsheet. The results of quantitative variables were described as mean, median and standard deviation. The qualitative variables were demonstrated by frequency and percentage. Data analysis was carried out using IBM SPSS Statistic Standard Software ${ }^{\circledR}$ v.20.0 on Windows ${ }^{\circledR}$.

\section{RESULTS}

From July 2010 to August 2012, 176 patients with a diagnosis of cancer were treated, spread among seven oncology services accredited by the health operator. 106 of these patients received at least one application of intravenous chemotherapy during their treatment in the study period. 65 of these were male and 41 male. The average age of patients was 67.2 years $( \pm 10,4)$.

1,284 applications of intravenous chemotherapy were conducted in total. The four main types of cancer treated with intravenous therapy were: breast (25), colorectal (24), lymphoma (18) and lungs (15).

The greatest number of applications were with fluorouracil (416), followed by leucovorin (289) and paclitaxel (162).

The sum of the prescribed dose, represented in milligrams, varied according to the amount of medication needed to meet the protocol defined by the oncologist.
The medications prescribed in higher doses were: fluorouracil $(809,396.00 \mathrm{mg})$, followed by gemcitabine $(185,780.00 \mathrm{mg})$ and leucovorin $(103,960.00 \mathrm{mg})$ (Table 1). The total dose of chemotherapy discarded in two years was $63,824.00 \mathrm{mg}$. The largest amount of chemotherapy discarded was fluorouracil $(29,354.00 \mathrm{mg})$, gemcitabine $(7420.00 \mathrm{mg})$ and trastuzumab $(6,946.00 \mathrm{mg})$. There was a loss of approximately $602 \mathrm{mg}$ of chemotherapy per patient and $49 \mathrm{mg}$ per application performed (Table 2).

Table 2 shows the analysis of the cost of chemotherapy waste produced in 2 years of monitoring. A total cost of BRL 448,397.00 was identified. The medications contributing most to this cost were: trastuzumab (BRL 140,763.37), bortezomib (BRL 89,556.25) and oxaliplatin (BRL 68,755.00). The average cost of the chemotherapy dose discarded per patient was BRL 4,607.00, and BRL 380.00 per application.

If all the chemotherapy was prepared in a single day at the same location (hypothetical centralized model), there would be a total of $971.80 \mathrm{mg}$ discarded. The cost of chemotherapy waste produced in this model would be BRL 13,991.64 (Table 2). The average cost of the chemotherapy dose discarded per patient would be BRL 132.00 and BRL 10.90 per application.

\section{Discussion}

This study portrays the cancer treatment model usually conducted in the private health system in Brazil. ${ }^{5,9}$ Most cancer treatment services are centralized in large cities and have their own chemotherapy preparation unit. The health provider evaluated is part of the self-management category and features a total of 16,660 beneficiaries. In the State of Paraná, only $25 \%$ of the population $(2,882,000$ people) is covered by a private health plan. Only $12.3 \%$ of these are self-management operators, covering $8 \%$ of the total beneficiaries in the state. ${ }^{18}$ Therefore, the study data only represents a small percentage of the impact of chemotherapy waste in the city of Curitiba. Even so, it was shown that the medication volume discarded in the 2-year period was significant $(63.824 \mathrm{mg})$, reaching $602 \mathrm{mg}$ per patient and $49 \mathrm{mg}$ per application.

The cost of chemotherapy waste is often passed on to the healthcare provider because the charge relates to the number of vials and ampoules used and not the amount in milligrams prescribed by the physician. In two years of observation, the total cost of chemotherapy waste was BRL 448,397.00, representing BRL 4,607.00 per patient and BRL 380.00 per application performed. The value of the waste was calculated based on the factory price practiced in the State of Paraná. If considered the amount negotiated between the health provider and the service provider ( 32 to $38 \%$ of the factory price), the 
real cost of chemotherapy waste in two years could reach BRL $674,000.00$, with an average cost of waste per patient of BRL 6,358.00.

The centralization of chemotherapy preparation may be an appropriate strategy to reduce waste. The greater the number of medical prescriptions for chemotherapy prepared in one location, the more likely that such medication will be used in a single day, allowing for better use of chemotherapy leftovers. There are no studies compar- ing centralization versus decentralization in the preparation of chemotherapy medication. In order to evaluate this difference, a hypothetical model of centralized chemotherapy preparation was developed, with an estimated calculation of the reduction of medication waste produced. As such, if all the applications were prepared in a single day and location, there would be a 65 -fold reduction in the volume of waste and 35 -fold reduction in the cost of discarded chemotherapy.

\section{TABLE 1 Analysis of chemotherapy residue produced by the study sample.}

\begin{tabular}{|c|c|c|c|c|c|c|}
\hline $\begin{array}{l}\text { Chemotherapy } \\
\text { (CT) }\end{array}$ & $\begin{array}{l}\text { Presentation } \\
\text { dose }(\mathrm{mg})\end{array}$ & $\begin{array}{l}\text { Total number } \\
\text { of applications }\end{array}$ & $\begin{array}{l}\text { Number } \\
\text { of patients }\end{array}$ & $\begin{array}{l}\text { Sum of the total pre- } \\
\text { scribed dose (mg) }\end{array}$ & $\begin{array}{l}\text { Sum of the total dis- } \\
\text { carded dose (mg) }\end{array}$ & $\begin{array}{l}\text { Average discarded } \\
\text { dose per } \\
\text { application }(\mathrm{mg})\end{array}$ \\
\hline Fluorouracil & 500 & 416 & 31 & 809396 & 29354 & 70.56 \\
\hline Gemcitabine & 200 & 99 & 13 & 185780 & 7420 & 74.95 \\
\hline Trastuzumab & 440 & 48 & 5 & 19894 & 6946 & 144.71 \\
\hline Leucovorin & 50 & 289 & 19 & 103960 & 3805 & 13.17 \\
\hline Cetuximab & 100 & 130 & 8 & 71197 & 3523 & 27.1 \\
\hline Cyclophosphamide & 200 & 103 & 22 & 93832 & 3164 & 30.72 \\
\hline Oxaliplatin & 50 & 139 & 12 & 23528 & 2072 & 14.91 \\
\hline Bevacizumab & 100 & 69 & 9 & 36584 & 1516 & 21.97 \\
\hline Irinotecan & 40 & 134 & 11 & 30716 & 784 & 5.85 \\
\hline Etoposide & 100 & 42 & 4 & 5571 & 729 & 17.36 \\
\hline Paclitaxel & 30 & 162 & 23 & 26597 & 593 & 3.66 \\
\hline Pemetrexed & 100 & 41 & 7 & 24960 & 540 & 13.17 \\
\hline Methotrexate & 500 & 18 & 4 & 1290 & 510 & 28.33 \\
\hline Carboplatin & 50 & 77 & 19 & 30891 & 509 & 6.61 \\
\hline Decitabine & 50 & 21 & 3 & 600 & 450 & 21.43 \\
\hline Docetaxel & 20 & 69 & 16 & 8490 & 390 & 5.65 \\
\hline Mitoxantrone & 20 & 23 & 2 & 1623 & 390 & 16.96 \\
\hline Rituximab & 100 & 107 & 10 & 68141 & 259 & 2.42 \\
\hline Cisplatin & 10 & 73 & 16 & 6575 & 165 & 2.26 \\
\hline Doxorubicin & 10 & 81 & 18 & 6680 & 150 & 1.85 \\
\hline Vinorelbine & 10 & 30 & 4 & 1101 & 149 & 4.97 \\
\hline $\begin{array}{l}\text { Liposomal } \\
\text { doxorubicin }\end{array}$ & 20 & 22 & 3 & 1200 & 120 & 5.45 \\
\hline Fludarabine & 50 & 19 & 2 & 845 & 105 & 5.53 \\
\hline Bortezomib & 3.5 & 79 & 5 & 177.3 & 99.5 & 1.26 \\
\hline Bleomycin & 15 & 18 & 2 & 230 & 40 & 2.22 \\
\hline Vinblastine & 10 & 18 & 2 & 140 & 40 & 2.22 \\
\hline Vincristine & 1 & 28 & 6 & 54.5 & 1.5 & 0.05 \\
\hline Dacarbazine & 200 & 16 & 3 & 13200 & 0 & 0 \\
\hline
\end{tabular}


TABLE 2 Chemotherapy waste comparison between the study sample and the hypothetical model of centralized drug preparation.

\begin{tabular}{|c|c|c|c|c|c|}
\hline Chemotherapy (CT) & $\begin{array}{l}\text { Cost per } \\
\text { milligram }(\mathrm{mg})^{1}\end{array}$ & $\begin{array}{l}\text { Waste } \\
\text { produced }(\mathrm{mg})^{2}\end{array}$ & $\begin{array}{l}\text { Cost of waste } \\
\text { produced }\end{array}$ & $\begin{array}{l}\text { Hypothetical } \\
\text { waste }(\mathrm{mg})^{3}\end{array}$ & $\begin{array}{l}\text { Cost of hypothet- } \\
\text { ical waste }\end{array}$ \\
\hline Trastuzumab (Herceptin) & BRL 20.27 & 6946 & BRL $140,763.37$ & 346 & BRL 7,013.42 \\
\hline Bortezomib (Velcade) & BRL 900.06 & 99.5 & BRL 89,556.25 & 2.3 & BRL 2,070.14 \\
\hline Oxaliplatin (Eloxatin) & BRL 33.18 & 2072 & BRL $68,755.18$ & 22 & BRL 729.96 \\
\hline Decitabine (Dacogen) & BRL 88.16 & 450 & BRL 39,672.45 & 0 & BRL 0.00 \\
\hline Cetuximab (Erbitux) & BRL 6.78 & 3523 & BRL 23,870.44 & 3 & BRL 20.34 \\
\hline Bevacizumab (Avastin) & BRL 12.33 & 1516 & BRL 18,691.07 & 16 & BRL 197.28 \\
\hline Mitoxantrone (Evomixan) & BRL 46.88 & 390 & BRL $18,281.64$ & 17 & BRL 796.96 \\
\hline Docetaxel (Taxotere) & BRL 43.56 & 390 & BRL 16,988.60 & 10 & BRL 435.60 \\
\hline $\begin{array}{l}\text { Liposomal doxorubicin } \\
\text { (Doxopeg) }\end{array}$ & BRL 96.11 & 120 & BRL $11,533.74$ & 0 & BRL 0.00 \\
\hline Paclitaxel (Taxol) & BRL 19.29 & 593 & BRL 11,438.97 & 3 & BRL 57.87 \\
\hline Irinotecan (Camptosar) & BRL 13.90 & 784 & BRL 10,900.93 & 24 & BRL 333.60 \\
\hline Fludarabine (Fludara) & BRL 61.00 & 105 & BRL $6,404.50$ & 5 & BRL 305.00 \\
\hline Leucovorin (Fauldleuco) & BRL 1.56 & 3805 & BRL 5,941.13 & 40 & BRL 62.40 \\
\hline Pemetrexed (Alimta) & BRL 10.66 & 540 & BRL 5,758.18 & 40 & BRL 426.40 \\
\hline Rituximab (Mabthera) & BRL 21.24 & 259 & BRL 5,501.86 & 59 & BRL 1,253.16 \\
\hline Gemcitabine (Gemzar) & BRL 0.68 & 7420 & BRL 5,041.52 & 20 & BRL 13.60 \\
\hline Vinorelbine (Navelbine) & BRL 17.45 & 149 & BRL 2,599.31 & 9 & BRL 157.05 \\
\hline Carboplatin (Fauldcarbo) & BRL 4.47 & 509 & BRL 2,276.66 & 9 & BRL 40.23 \\
\hline Fluorouracil (Fauldfluor) & BRL 0.04 & 29354 & BRL $1,129.78$ & 104 & BRL 4.16 \\
\hline Doxorubicin (Faulddoxo) & BRL 7.00 & 150 & BRL $1,050.45$ & 0 & BRL 0.00 \\
\hline Cisplatin (Fauldcis) & BRL 4.78 & 165 & BRL 788.70 & 5 & BRL 23.90 \\
\hline Bleomycin (Bonar) & BRL 14.66 & 40 & BRL 586.24 & 0 & BRL 0.00 \\
\hline Etoposide (Eunades) & BRL 0.31 & 729 & BRL 225.30 & 29 & BRL 8.99 \\
\hline Methotrexate (Fauldmetro) & BRL 0.43 & 510 & BRL 220.35 & 40 & BRL 17.20 \\
\hline Vinblastine (Faublastina) & BRL 5.26 & 40 & BRL 210.30 & 0 & BRL 0.00 \\
\hline Cyclophosphamide (Genuxal) & BRL 0.05 & 3164 & BRL 163.09 & 168 & BRL 8.40 \\
\hline Vincristine (Fauldvincri) & BRL 31.96 & 1.5 & BRL 47.94 & 0.5 & BRL 15.98 \\
\hline Dacarbazine (Fauldacarb) & BRL 0.69 & 0 & BRL 0.00 & 0 & BRL 0.00 \\
\hline Total & & 63824 & BRL $488,397.95$ & 971.8 & BRL 13,991.64 \\
\hline
\end{tabular}

'According to the Brasindice Pharmaceutical Guide 2014, factory price at 12\%.

${ }^{2} \mathrm{Sum}$ of the total amount of chemotherapy waste produced in the sample studied.

${ }^{3} \mathrm{Sum}$ of the total quantity of chemotherapy residue produced if all drugs were prepared in the same day and place.

Furthermore, it can be assumed that centralization would enable better management of chemotherapy waste and medical prescriptions, standardization of medications with more convenient commercial presentations, early planning of the intended treatment per week and better quality control to the process. ${ }^{11,22,23}$ Fasola et.al. demonstrated that the management of waste in a centralized medication preparation unit may reduce chemotherapy by $45 \%$ in two years of monitoring. 15,16
Centralization in medication preparation can bring benefits to oncology services. Both the implementation and maintenance of a chemotherapy preparation unit are costly, and they will no longer be necessary. Expenses with management of high-cost medication stocks, including the costs of expired medications, safety and delay to the start of treatment due to lack of chemotherapy will be avoided. Oncology services can prioritize resources on physical facilities and hiring human resources to ensure 
comfort, safety and quality in customer service and application of chemotherapy. Health providers may accredit chemotherapy preparation units to supply the medication directly to oncology services. Payment to the service provider could then be made for the prescribed dose and not the number of flasks and ampoules used. Therefore, the health provider no longer pays for the cost of discarded chemotherapy. Lastly, centralization allows for better supervision of the units by the competent authorities (Anvisa), ensuring the safety and quality of the final product to health plan beneficiaries.

On the other hand, some difficulties can be expected in the centralized system. One is the need for quality logistical support. There is also a need to transport the final product to the oncology clinics on time, as well as the removal of the toxic waste produced. Therefore, the distance between the clinics and the chemotherapy preparation unit should be feasible for the service to be provided with quality. Another challenge is the need for an efficient communication channel between services. Medical prescriptions need to be made upon prior assessment of the patient. Situations such as changes in weight, side effects of treatment and changes in laboratory tests can result in changes to medication dosage, changes in chemotherapy protocol or temporary suspension of treatment. Therefore, prior communication between the clinic and chemotherapy preparation unit is essential, with notification of changes in treatment. An information technology system could be a strategy to ensure efficient communication between services.

\section{Conclusion}

Chemotherapy medication waste in the preparation process can be significant, resulting in toxic waste production and increased cost of cancer treatment. The centralized chemotherapy preparation model could be a suitable strategy for better management of chemotherapy waste. New studies can contribute to the validation of this hypothesis, as well as to define a minimum coverage of a centralized chemotherapy unit to justify its implementation (coverage area, population served and minimum number of applications prepared daily).

\section{Resumo}

Uma análise preliminar da redução do resíduo de quimioterapia no tratamento do câncer com a centralização no preparo da medicação

Introdução: a quimioterapia é essencial no tratamento da maioria dos tipos de câncer. No processo de preparo da quimioterapia, com frequência, parte da medicação precisa ser descartada para se atingir a dose prescrita pelo médico. A dose excedente da medicação resulta na produção de resíduo tóxico.

Objetivo: analisar a redução do resíduo de quimioterapia obtida por meio da centralização do preparo da medicação.

Metodologia: foi realizado um estudo transversal observacional e descritivo entre 2010 e 2012, a partir da análise das prescrições de quimioterapia, pela auditoria médica de um plano de saúde, no estado do Paraná. Foi calculada a dose de quimioterapia desprezada e o seu custo, em cada aplicação, considerando a dose prescrita pelo médico e as apresentações comerciais das drogas. A mesma análise foi realizada em um modelo hipotético centralizado de preparo de quimioterapia.

Resultados: foram identificados 176 pacientes, com diagnóstico de câncer, sendo que 106 pacientes realizaram um total de 1.284 aplicações endovenosas. Houve um total de $63.824 \mathrm{mg}$ de resíduo de quimioterapia com custo de $\mathrm{R} \$ 448.397,00$. O custo médio de quimioterapia desprezada por paciente foi de $\mathrm{R} \$ 4.607,00$. No modelo centralizado de preparo houve $971,80 \mathrm{mg}$ de resíduo com custo de R\$13.991,64. Nesse modelo, o custo médio de quimioterapia desprezada por paciente seria de R $\$ 132,00$. Conclusão: conclui-se que a centralização no preparo da medicação para o tratamento do câncer pode ser uma estratégia para reduzir os resíduos de quimioterapia.

Palavras-chave: quimioterapia, administração de serviços de saúde, boas práticas de manipulação, resíduos de serviços de saúde, neoplasias.

\section{References}

1. Goulart FAA. Doenças crônicas não transmissíveis: estratégias de controle e desafios e para os sistemas de saúde. Organização Pan-americana da Saúde/ Organização Mundial da Saúde. 2011. p.1-96. Available at: http://apsredes. org/site2012/wp-content/uploads/2012/06/Condicoes-Cronicas_flavio1.pdf.

2. Pan American Health Organization (PAHO) / World Health Organization (WHO). Improving chronic illness care through integrated health service delivery networks. Washington, D.C.: OPS, 2012.

3. Instituto Nacional de Câncer José Alencar Gomes da Silva (INCA). Coordenação Geral de Ações Estratégicas. Coordenação de Prevenção e Vigilância. Estimativa 2014: Incidência de câncer no Brasil. Rio de Janeiro. Available at: http://www.inca.gov.br/estimativa/2014/.

4. Schmidt MI, Duncan BB, Silva GA, Menezes AM, Monteiro CA, Barreto SM, et al. Chronic non-communicable diseases in Brazil: burden and current challenges. Lancet. 2011;377(9781):1949-61.

5. Gross PE, Lee BL, Badovinac-Crnjevic T, Strasser-Weippl K, Chavarri-Guerra Y, St Louis J, et.al. Planejamento do controle do câncer na América Latina e no Caribe. Lancet Oncology. 2013; 14(15):391-436.

6. Mariotto AB, Yabroff KR, Shao Y, Feuer EJ, Brown ML. Projections of the Cost of Cancer Care in the United States: 2010-2020. J Natl Cancer Inst. 2011; 103(2):117-28. 
7. De Vitta VT, Hellman S, Rosenberg SA. Cancer: principles and practice of oncology. 9.ed. Philadelphia: Lippincott Williams \& Wilkins, 2011.

8. Brasil. Resolução RDC n. 220, de 21 de setembro de 2004. Aprova o regulamento Técnico de funcionamento dos Serviços de Terapia Antineoplásica. Diário Oficial da União, Poder Executivo, de 23 de setembro de 2004.

9. Paim J, Travassos C, Almeida C, Bahia L, Macinko J. O sistema de saúde brasileiro: história, avanços e desafios. Lancet. 2011; 377(9779):11-31.

10. Instituto Nacional de Câncer José Alencar Gomes da Silva. Tratamento do Câncer no SUS. Available at: http://www.inca.gov.br/situacao/arquivos/ acoes_tratamento_cancer_sus.pdf.

11. Andrade CC. Farmacêutico em oncologia: interfaces administrativas e clínicas. Pharmacia Brasileira - mar/abr 2009. Available at: http://www.sbrafh.org. br/site/index/library/id/57.

12. Brasil. Ministério da Saúde. Agência Nacional de Vigilância Sanitária. Resolução RDC n. 33, de 25 de fevereiro de 2003. Dispõe sobre o Regulamento Técnico para o gerenciamento de resíduos de serviços de saúde. Diário Oficial da União da República Federativa do Brasil, Brasília, 2003.

13. Smith C, Allen C, Burke M, et.al. Managing pharmaceutical waste: a 10-step blueprint for healthcare facilities in the United States. Healthcare Environmental Resource Center (HERC), 2008. Available at: http://www. hercenter.org/hazmat/tenstepblueprint.pdf

14. Giusti L. A review of waste management practices and their impact on human health. Waste Manag. 2009; 29(8):2227-39.
15. Fasola G, Aita M, Marini L, Follador A, Tosolini M, Mattioni L, et al. Drug waste minimisation and cost-containment in Medical Oncology: two-year results of a feasibility study. BMC Health Serv Res. 2008; 8:70.

16. Fasola G, Aprile G, Marini L, Follador A, Mansutti M, Miscoria M. Drug waste minimization as an effective strategy of cost-containment in Oncology. BMC Health Serv Res. 2014, 14:57.

17. Abraham J. Developing oncology biosimilars: an essential approach for the future. Semin Oncol. 2013; 40(Suppl 1):S5-24.

18. Brasil. Ministério da Saúde, Agência Nacional de Saúde Suplementar (ANS) Atlas econômico-financeiro da saúde suplementar 2013, Ano 9 (abr. 2014), Rio de Janeiro.

19. Loverdos A. Auditoria e análise de contas médico-hospitalares. São Paulo: Editora STS, 1999. 226p.

20. Sociedade Brasileira de Oncologia Clínica (SBOC). Guia de orientações médicas para auditoria em oncologia. 2009-2011. Available at: http://www. sboc.org.br/app/webroot/manual-auditoria/

21. Guia Farmacêutico Brasíndice 796, ano 49 - 10 de janeiro 2014. São Paulo: Editora Andrei, 2014

22. Spiller ES, Senna AM, Santos JF, Vilar JM. Gestão dos serviços de saúde. Rio de Janeiro: FGV, 2009.

23. Porter ME. Repensando a saúde: estratégias para melhorar a qualidade e reduzir custos. Porto Alegre: Bookman, 2007. 